\title{
Translation: ‘An Epistle from God' by Yeremei Aipin
}

OLIVER TASLIC

University of Bristol

\section{ACKNOWLEDGEMENTS}

Oliver Taslic would like to thank Yeremei Aipin for his permission to publish this translation. He would also like to thank Dr Josephine von Zitzewitz for her help and support with this translation.

\section{INTRODUCTION}

Yeremei Aipin (b. 1948) is Russia's foremost Khanty author. The Khanty, sometimes known as the Ostyaks, are an indigenous people in west Siberia and number about 30,000. Among other things, they are notable for their role in the Kazym rebellion (c. 1931-34), which was the last known conflict between the Soviet authorities and an indigenous Siberian people, and upon which the following story touches. Although many of Aipin's works are available in other languages, he has not been widely published in English. The British Library, for example, stocks just one such book. The following translation of 'An Epistle from God' (1990), an accessible, entertaining, and thoughtful short story, seeks to change this. It is worth mentioning that the following translation has been slightly abridged (the first two chapters have been redacted), and that it was translated from the original Russian, not from Khanty (although the Khanty language is mentioned in the story).

\section{‘AN EPISTLE FROM GOD’ BY YEREMEI AIPIN}

We had more than enough of the war in our Land. It travelled up and down the rivers. Then it set off towards the Sunrise. Lyonya Lipetsky left along with the war. By that time, the Whites had conferred on him the rank of commander in recognition of his military know-how; he became the head of their detachment. 
A great deal of water flowed in the Ob. The war ended.

The Reds beat the Whites.

Not one bullet touched Lyonya Lipetsky. Not one sabre scratched him. Not one piece of shrapnel struck him. He remained safe and sound. It seemed that the Epistle from God had protected him. Just before leaving for war he had sewn a little leather bag, stowed the Epistle from God inside it and hung it from his neck under his shirt. And from then on, he never parted with the Epistle from God.

So then, the war between the Reds and the Whites ended. The war had taken Lipetsky to the ends of the earth. He spent a stint wandering around distant lands before returning home. There's no life, he used to say, without one's land, where one was born and grew up. I don't know, I don't remember exactly, whether it was straight away, or a short time afterwards, that a rumour reached the town that Lyonya Lipetsky, who fought for the White Tsar, had returned. Anyway, he himself didn't hide the fact that he'd fought on the White side.

The Reds rigged up an interrogation for him. First things first, they said, tell us, Lipetsky:

'You went to war?'

'I did,' replied Lipetsky.

'Fought for the Whites?'

'For the Whites.'

'Went to free the White Tsar?'

'I went to save him.'

'So why didn’t you?!'

'Regretfully, I didn't make it in time.'

'Did you kill Reds?'

'In battle I did.'

'Are you going to answer for all this?'

'I will,' Lipetsky said calmly.

'You've got nowhere to run off to,' the Reds laughed. 'So you've really got no choice but to answer! You see, we'll whip up an investigation, gather all your sins into one pile, weigh them up and take you to trial before the revolutionary-proletarian law of our workers and peasants' state! And you'll be subjected to our law in the strictest possible sense!' 
Lipetsky was silent. Silent for a long time.

Then he said:

'Okay, but first explain something to me that I don't understand.'

'Ask away,' the Reds said. 'We'll spell it out for you - we'll bring light to that barren head of yours!'

And Lipetsky asked:

'First of all, tell me: who's going to take responsibility for the Whites that were killed?'

'The Whites went against the people, there's nothing to take responsibility for!' said the Reds.

'Who's going to take responsibility for the White Tsar, murdered unjustly and unlawfully?’ asked Lipetsky.

'He was a tyrant of the people, he got what was coming to him!' the Reds replied.

'Who's going to take responsibility for the White Tsarina, murdered unjustly and unlawfully?’

'She was also a tyrant of the people, she got what was coming to her!'

'Who's going to take responsibility for the White Tsar's murdered children?!'

'Quiet!' shouted the Reds.

'Who's going to take responsibility for the White Tsar's murdered daughters?!'

'Quiet!!' the Reds roared.

'Who's going to take responsibility for the White Tsar's murdered son?!'

'Quiet!!!' the Reds howled.

'Did you summon me here to talk or to be quiet?!' asked Lipetsky.

Once the Reds had calmed down a little, they reminded him:

'Don't forget yourself, Lipetsky - you're in our hands!'

'I'll never be in your blood-stained hands,' said Lipetsky. 'My life is in the hands of my Heavenly Father. What he decides goes.'

The Reds chuckled incredulously.

But Lipetsky did not ask the Reds about the White Tsar's family unduly. It all happened as he said it did. When the Red Tsar seized power, they brought the White Tsar and his wife and children to our land. They held them here for a while. You see, Lipetsky used to recount how he and his soldiers went to save the Tsar's family, first to Tobolsk, then to Catherine-Tsarina City, as we called Yekaterinburg. But he didn't manage it in time; he 
was a little too late. And because of this he would blame himself, too, for their horrific deaths for as long as he lived.

'In any case, Lipetsky, you'll have to take responsibility,' said the Reds.

'I will do, but not before you,' replied Lipetsky.

'Before the law of the workers and peasants' state!'

'You have no laws whatsoever: not revolutionary-proletarian, not workers and peasants', not human.'

'That's where you're wrong, Lipetsky: we have just laws!'

'According to which you're able to rob the lives of innocent children?! And that's what you call just laws?!

'Quiet!!!' the Reds grew furious again. 'And what exactly were you doing during the Civil War?!'

'Guilty as charged,' said Lipetsky. 'But God sees: I didn't fight with women and children, didn't kill anyone unarmed, and didn't shoot anyone in the back.'

'Except we won,' said the Reds. 'And you, Lipetsky, you're not the judge of us, you don't get to order us around! We have our own leaders! And we ourselves know who to put on trial and who not to.'

'You don't know.'

'Why don't we know?'

'Your main enemy... isn't me...'

'Then who is it?'

'You yourselves.'

'How do you figure that out? Tell us!'

Lipetsky was silent for a while. He was mulling it over: should he tell them or not? Would they understand, or wouldn't they? But in the end, he spelt it out:

'You have no heart. The lot of you are like empty little nuts. From a distance it looks like an ordinary nut, but when you crack it... it's empty, there's nothing there. Pure emptiness...'

'So you've cracked us, you mean?'

'With God's help.'

'Sure, mind you don't break your teeth!' 
'Some saw through you straight away; others during the Civil War. And when the last people see through you and see that you have no centre, that you're empty - then the end will come for you.'

'And what don't we have? What should be there?'

'You have no faith, no God. And without God, you'll turn into beasts - you'll tear at each other's throats and that'll be the end of you.'

'But first we'll tear at your throats.'

'That's true. First us, and then you'll take on each other.'

'And according to you, Lipetsky, is that how life ends?'

'No, no, people will remain. But not Reds. Only people of faith, people of God...'

'So there won't be any of us then?'

'You don't wear a cross, so no, there won't be.'

'You're taking on a lot, Lipetsky - don't overburden yourself!'

'You've got blood on your hands... the earth simply won't bear you, it won't carry you...'

'You're not getting away from us now, Lipetsky,' said the Reds. 'You want to spend the last few days of your life prattling on about nothing? That's fine by us...'

'I'll get away,' Lipetsky assured them.

'And we'll catch you!' said the Reds. 'We'll break your legs, we'll cut your tongue out! We've dealt with harder than you before...'

'You could do. They don't call you the insatiably bloodthirsty Reds for nothing. You've justified your colour...'

'Hands off our revolutionary colour, Lipetsky! It won't end well for you!'

'It could hardly get any worse...'

'All the same, you won't get away! We'll pick up your trail!'

'I'll kill anyone you put on my trail.'

'Let's see who'll kill who, shall we?'

'It would be better to spare your people and leave me in peace.'

'We haven't the slightest intention of letting you rest - the Devil himself will wince at what we'll do to you!'

Lipetsky fell silent. Silent for a long time. Then he said to the Reds:

'I'm declaring war on you.'

'You, Lipetsky, have gone completely mad.' 
'On the contrary, I'm in my right mind.'

'There's just one of you, and lots of us. How can there be a war here?'

'That's my job, telling you.'

'What are you going to fight for? For the White Tsar?'

'For the White Tsar.'

'He's long gone - what do you need him for?'

'Ask the people which Tsar they need - the White or the Red? Then you'll understand.'

'Stop trying to side-track us, Lipetsky; there's no one for you to fight for. Everyone's gone, gone, and you won't bring them back!'

'There are people to fight for. For my wife. For my daughter. For the White Tsar's children. For all your innocent victims. Have you kept count of how many souls you've ruined?'

'Quiet!' the Reds shouted. 'That's none of your business. This is a revolution!'

'God will never forgive what you've done.'

And that's when the Reds shouted furiously:

'We, Lipetsky, we will shake that God of yours out of you right now, and you'll be just as red and as bloody as we are...'

'Well, that's really up to my Heavenly Father!' said Lipetsky.

And he escaped from the Reds. And that's when the real hunt for him started. The NKVD became 'hunters.' How many traps they laid for him! They didn't get him. How many crafty snares they tried to lure him into! Unsuccessfully. How many horses they drove to death in pursuit of him! More than one can count. How many companies of reindeer they ground down! Nobody kept count.

Lipetsky was elusive.

One time they tracked him down at his house. And a thick line of NKVD operatives surrounded the yard. Keeping their distance, they shouted:

'Lipetsky, throw down your weapons! Get out of there!'

'Lipetsky, surrender!'

'The house is surrounded, there's no way you're escaping!'

The house was silent.

The operatives stood, waited. 
Then they started shouting again:

'Lipetsky, surrender!'

'Lipetsky, get out of there!'

Here Lipetsky's voice could be heard from the house. He shouted:

'I'm getting dressed; I'm coming out now! Hold on!'

The NKVD braced themselves, steadied themselves. They kept their eyes peeled, lest they miss him. It was summer. And nobody paid any attention to the woman with the bucket. Women were often going out to collect water. The main thing was to catch Lipetsky.

They stood, waited.

How long did this man take to get dressed? They started shouting, hurrying him:

'Come on, faster!'

'Get out of there, come on!'

The house was silent.

They started shouting again.

But although the house was completely silent, the operatives could not bring themselves to approach it. They seemed rather scared of Lipetsky. And indeed, they had heard the rumours. They knew what he was like, how well he handled weapons. He handled weapons expertly. He could shoot scrap metal better than most people could shoot bullets. Not one of his bullets ever missed the target. He could shoot at night, in the dark. He could shoot without looking, blindfolded. He could shoot two pistols using two hands at the same time. How did he pull all this off? It's actually very simple, or so they say: where the eyes don't see, the ears hear. That is, he fired at sounds. Lipetsky used to say that, if you really want to survive, you'll learn anything. He said that war taught him a lot of necessary and unnecessary skills. Whenever he found himself in a particularly ticklish situation, he'd draw two shooters: one led by his eyes, and another by his ears. Just try going head to head with such a marksman. I mean, really, who would want to take a bullet to the forehead? Especially during peacetime.

He was crafty.

He was clever.

He was swift.

How did he escape from the Reds the first time? They tell it like it was. After their 'intimate' discussion, the Reds handed him over to the Reds in the NKVD. Lipetsky did not think to resist. He gave himself up to be searched. Meekly. They took away his belt, turned 
out his pockets, patted down his sides. They led him to prison. NKVD operatives ahead, NKVD operatives behind. They were leading him. Everything was quiet, calm. Suddenly, having picked his moment, he raised his arms sharply and drew two pistols from his sleeves. And two shooters at the same time: bang, bang, bang! He did a forward roll, quickly cartwheeled into the bushes, then into the grass, and he was gone.

He slipped down into the lowland, into a small hollow, reloaded his pistols there and was ready to fight again.

That's how he escaped from the Reds the first time.

And these NKVD operatives had probably heard about this story. That's why they were dragging their feet in indecision. A little more time passed. Something had to be done. And eventually, once their patience had completely run out, they moved on the house.

Silence. No noise, no shots.

They burst into the house.

In the house there was a canopy bed. They yanked open the curtains. But in the bed was a naked woman.

There was no trace of Lipetsky. He had changed into women's clothes, pulled a headscarf down over his eyes, and he was gone.

It would often happen that the NKVD would pick up Lipetsky's trail and race after him - at least until their horses collapsed. You see, it wasn't that Lipetsky had a flying horse. But he would always find a fresh one and give his pursuers the slip. Then his trail, as it were, would disappear quite unexpectedly. As if he'd vanished into thin air. His pursuers ransacked the whole region, but, in the end, left with nothing.

This convinced everyone once again that trying to catch Lipetsky was a pointless task.

Water turned to snow and to ice floes, and snow and ice to water.

That was how the years passed.

Here the tumultuous years came rolling in. The Ostyaks became out of control and rose up against the Reds. And the Reds rose up against the Ostyaks. ${ }^{1}$

\footnotetext{
${ }^{1}$ The Ostyaks were defeated by the Soviets in the Kazym rebellion c. 1931-34. It should be noted that while 1931-34 is the most widely accepted timeline, there is some variation. Ernykhova (2003) focuses on the rebellion's events 1933-34, while Aipin himself records it in a footnote as having taken place 1934-35.
} 
Soldiers and aeroplanes arrived from Catherine-Tsarina City. Across the ground and through the air, they moved along the big and small rivers.

That's how the war came to our land.

Some were killed by bullets.

Some were blown up by fiery stones. ${ }^{2}$

Some were frozen by the frost.

Some were butchered by larch-clubs. ${ }^{3}$

Some were tormented in dungeon-like prison cells.

Not one of them made it to the prison camp...

The tumultuous times went by, rolled on by. But the soldiers continued to scour the rivers for a long time after. From the mouth to the source, from the source to the mouth, they dragged their 'seines." They sieved through everything. They would fish out everyone who was involved and everyone who wasn't involved... and they dealt with everyone in the same way. Get caught and you'd be held responsible in accordance with all the severity of wartime. Later, the NKVD started to lay their own nets and traps. With extraordinary enthusiasm, they watched over and listened in on every river, every marsh, and every lake through which insurgents had passed and fighting had taken place.

The waters and lands of many of our rivers were ransacked from top to bottom.

However, despite the endless seines and densely strewn nets and traps, they did not get Lipetsky.

But they all searched for him, they all tried to catch him.

One winter, our house was swamped by travellers and guests. Some were travelling to the head of the river, others to the mouth. Some were travelling on business, others were visiting their families. Some were going into town, some were coming from there. We would all sit at one big table, drink tea and exchange news. One time, the dogs in the street started barking. New companies of horses approached, and new travellers entered the house. As is our custom, we poured the guests tea and sat them at the table. We chatted a little more. It became apparent that the visitors were two or three NKVD operatives and a translator, travelling in search of 'enemies of the people'. One of them, having talked about this and that, asked through the translator:

\footnotetext{
2 The Khanty called grenades fiery stones.

${ }^{3}$ A larch is a type of conifer found in Siberia and North America.

${ }^{4}$ A type of vertical fishing net.
} 
'Heard anything about Lipetsky?'

The hunter sitting alongside him, sipping tea from a saucer, asked in Khanty through the translator:

'Which Lipetsky?'

'The one that fought for the Whites.'

'We weren't there; how should we know which Lipetsky fought for the Whites and which for the Reds? See here, there's more than a few Lipetskys in this world...'

'I'm asking about Lyonya Lipetsky, the one we're searching for...'

'Uh-huh, go on...'

'So, what have you heard about Lyonya?'

'Not heard anything about him.'

'He hasn't turned up around your river?'

'Not heard any rumours.'

'Hey, look!' the NKVD operative said sternly. 'We need his head.'

'So you're saying he has a particularly valuable head, is that right?'

'That's right - we've paid dearly for his head.'

'If only someone valued our heads so highly,' the hunter joked, 'maybe I'd give you mine...'

But the operative wasn't in the mood for jokes. He reminded him again, with a hint of a threat:

'See here, the moment Lipetsky turns up around your river, you let us know in town right away!'

'Aha, of course, right away!' the hunter, his interlocutor, agreed. 'Just let him show up here! We'll let you know, patience!'

So, the operative and the hunter would sit side by side, drink tea and, through the translator, start talking about how to catch Lipetsky. And it never occurred to the NKVD operatives that this sinewy hunter in his traditional fur-lined coat and boots was Lyonya Lipetsky himself.

This happened more than once. Lipetsky would sit alongside the operatives and debate how best to lure himself into the NKVD's 'nets.' While he was at it, he would, of course, try to tease out what the operatives had heard about Lipetsky lately. That is, about himself. Where had they seen him? What rumours about him were making the rounds? Of course, he would also ferret other information that was useful to him out of the NKVD. 
Almost certainly, it had not occurred to any of the operatives that they had been sitting at the same table as Lyonya Lipetsky, drinking tea with him and letting slip various pieces of information. So long as, of course, Lipetsky did not reveal himself. They say that he would sometimes play various tricks on his pursuer, as it were. He would chat for a while with the operative, drink some tea with him, and then announce, in the cleanest Russian:

'You need Lipetsky? I'm Lipetsky, take me!'

The operative would usually leap out of his chair and shout:

'Under arrest! Hands up!'

Lipetsky would raise his hands a little, then make an obscene gesture and ask derisively:

'Is this not what you wanted?!'

'Stop! I'll shoot!' the operative would shout, then move his hand towards the holster at his side.

'Hmm, so what, you're going to shoot?!' Lipetsky would roar with laughter in the operative's face.

The holster would turn out to be empty. Or a revolver without ammunition. Click, click: nothing.

Here Lipetsky would jump onto his horse or into his sledge, and he was gone.

In his rage, the hapless NKVD operative would launch himself at the people, at the populace:

'Why didn't you hand him over?!'

'It's not written on his forehead that that's who he is...' the people would throw up their hands.

'Why did you let him in your house?!'

'Travellers usually enter the house without asking any questions...'

'Why did you give him tea?!' the operative would ask, boiling with rage.

'It's our custom to pour all our guests tea...'

The operative, cooling down, would promise significantly:

'Just you watch out!'

However, usually Lyonya Lipetsky would sit peacefully, slurp his tea and laugh a little, while the operative, through the translator, quizzed him about himself. And, well, he'd show an interest in assisting them in their search for Lipetsky, in letting the NKVD know if he emerged. 
That's what Lyonya Lipetsky was like. He wasn't scared of anything. He wasn't scared of anyone.

My ancient brother-in-law fell silent.

The house was also silent.

And so was I.

Then, as if he had perceived our silent question, my elderly brother-in-law asked:

'Why couldn't they catch him?'

And having held the necessary pause, he himself replied:

'He never once laid a hand on the common people, never offended them. Neither Khanty, nor Russians.'

The old man was silent again, then asked:

'Who were the NKVD searching for? A Russian man, a White officer, correct?'

'That's correct.'

'Well, almost...' my brother-in-law smiled, 'Except Lipetsky was completely like a Khanty. He wore our clothes. He rode reindeer. He was skilled with a knife and with an axe. He stood strong in our traditional hunting skis. In a word, you wouldn't be able to tell the difference between him and a Khanty...'

The old man became lost in thought and lowered his head. He touched my knee and said:

'And he spoke Khanty better than you or me...'

'Tell me...'

The time for evening tea arrived. Afterwards, once everyone had taken some time to unwind, I asked my elderly brother-in-law:

'Does Lipetsky's story have an end, brother-in-law?'

'It does,' the old man answered.

'So they didn't get him, then?'

'No.'

'So how did it all end?'

'This is how it all ended,' the old man took a deep breath. 'I shall tell you now...' He fell silent heavily. And having fallen silent, began: 
'Lipetsky lived at my second cousin Kirill's on a neighbouring tributary of our Bolshaya River. He spoke a lot about the war. In battle, such as it was, it was kill or be killed. War, he used to say, is an awful thing. We, as people, are responsible for it. And people give their lives to assuage this guilt. This is understandable to some extent. But most of all, he used to say, he felt sorry for the horses, because the horses aren't responsible for any of it...'

So, Lipetsky lived at my second cousin Kirill's. But he only lived there during the winter. Once spring set in and the ice thawed, he would leave for the $\mathrm{Ob}$ for the whole summer. During the autumn, just before the ice set in, before the first snows and ice set in, he would return to cousin Kirill's for the winter.

That was how he lived: summer on the Ob, winter here.

A few winters and summers passed this way. A lot of water flowed during those years.

Consider this.

The war between the Whites and the Reds ended.

The other war between the Ostyaks and the Reds ended.

Another few winters and summers flew by and yet another war started far away from our land. We all remember this war well. They hauled off a lot of our people for this war. They even carried off my two brothers to fight in this war. Well, they never returned - they vanished without a trace, gone to the Nether World. As the Russians say, they died.

During the first year of this war, at the beginning of winter, Lyonya Lipetsky fell ill at cousin Kirill's. His hands and feet started to swell up. And that's when he told his hosts: 'enough, I'm not going to recover, I'm done for.'

Then he added these words:

'Now,' he said, 'you may hand me over to the NKVD if you want. Go to town and let them know - I won't hold it against anyone. You've given me,' he said, 'many days and years of life...'

However, as is customary with all weak and infirm people, they tended to him, treated him. But his words came true: he was ill for a while, some more time passed, and he died. 
As is customary with all those who have reached the end of the Middle World's road of life, they buried him in the ancestral graveyard with all the rites.

Yet more time passed, but that same winter news of his demise reached the NKVD and the town. And three NKVD operatives arrived from the town and demanded that the locals show them Lyonya Lipetsky's grave. The locals escorted them to the ancestral graveyard, to the grave. Here the operatives ordered them to dig up the corpse. But all the Khanty who were there flatly refused. For the Khanty there's no greater sin than disturbing the remains of someone who's left for the Nether World. For this reason, the Khanty would not touch the grave for the life of them. So the operatives started digging up the corpse themselves. It was obvious that a lot of time had passed since the day of the funeral. The ground had completely frozen through; it would not take either spades or axes. So they brought pick axes. And they started rapping at the grave with them. Well, two of them did. As for the third one, the more senior operative, he traipsed around, played the big man, ordered them around.

Eventually, and after much effort, they emptied the grave.

The operatives hauled out his corpse and searched it. They found a bit of money on him, but nothing else.

Who knows what they were searching for. Perhaps they'd heard about the Epistle from God, perhaps that's what they were searching for. But the Epistle from God was not to be found around Lipetsky's neck. I haven't the faintest idea where he hid it before he died - nobody does. It remained his secret.

So that's how Lyonya Lipetsky, even in death, had duped the NKVD again and left them with nothing.

That's when the senior operative grabbed the pick axe and thrust its spike into the corpse's head. And he stabbed at it with the pick axe furiously and repeatedly. And he smashed dead Lyonya Lipetsky's head to pieces.

The people who were there turned away and lowered their eyes.

And they were silent.

Silent...

Shortly before he died, as if he were already delirious, Lipetsky would sigh constantly: 'Oh, Russia, they've ruined so many people...' Then he would ask, already more intelligibly: 'And for what?! For what?!' 
TASLIC - TRANSLATION: ‘AN EPISTLE FROM GOD’ By YEREMEI AIPIN

And so, not having received an answer to his agonising question, Lyonya Lipetsky left for the Nether World.

Later, once the NKVD operatives had left, people buried the wretched ice pick in the ancestral graveyard.

The old man fell silent.

The house was also silent.

And it was as if, through their silence, they were honouring the memory of every person sent prematurely and violently to the Nether World.

This work is licensed under a Creative Commons Attribution-Non-commercial-No Derivatives 4.0 International License. To view a copy of this license, visit https:/ / creativecommons.org/licenses/by-nc-nd/4.0/. 